\title{
Integrating land cover and terrain characteristics to explain plague risks in Western Usambara Mountains, Tanzania: a geospatial approach
}

PROCHES HIERONIMO', JOEL MELIYO², HUBERT GULINCK ${ }^{3}$, DIDAS N. KIMARO ${ }^{*}$, LOTH S. MULUNGU ${ }^{4}$, NGANGA I. KIHUPI ${ }^{1}$, BALTHAZAR M. MSANYA ${ }^{2}$, HERWIG LEIRS ${ }^{5}$ and JOZEF A. DECKERS 3

${ }^{1}$ Department of Agricultural Engineering and Land Planning, Sokoine University of Agriculture, P.O. Box 3003, Morogoro, Tanzania

${ }^{2}$ Department of Soil Science, Sokoine University of Agriculture, P.O. Box 3008, Morogoro, Tanzania

${ }^{3}$ Department of Earth and Environmental Sciences, University of Leuven, Celestijnenlaan 200E, Leuven, Belgium

${ }^{4}$ Pest Management Centre, Sokoine University of Agriculture, P.O. Box 3110, Morogoro, Tanzania

${ }^{5}$ Evolutionary Ecology Group, Universiteit Antwerpen, Groenenborgerlaan 171, B-2020 Antwerpen, Belgium

\begin{abstract}
Literature suggests that higher resolution remote sensing data integrated in Geographic Information System (GIS) can provide greater possibility to refine the analysis of land cover and terrain characteristics for explanation of abundance and distribution of plague hosts and vectors and hence of health risk hazards to humans. These technologies are not widely used in East Africa for studies on diseases including plague. The objective of this study was to refine the analysis of single and combined land cover and terrain characteristics in order to gain an insight into localized plague infection risks in the West Usambara Mountains in north-eastern Tanzania. The study used a geospatial approach to assess the influence of land cover and terrain factors on the abundance and spatial distribution of plague hosts (small mammals) and plague vectors (fleas). It considered different levels of scale and resolution. Boosted Regression Tree (BRT) statistical method was used to clarify the relationships between land cover and terrain variables with small mammals and fleas. Results indicate that elevation positively influenced the presence of small mammals. The presence of fleas was clearly influenced by land management features such as miraba. Medium to high resolution remotely sensed data integrated in a GIS have been found to be quite useful in this type of analysis. These findings contribute to efforts on plague surveillance and awareness creation among communities on the probable risks associated with various landscape factors during epidemics.
\end{abstract}

Keywords: land cover, remote sensing, GIS, small mammals, fleas, plague, Tanzania

\section{Introduction}

Transmission of zoonotic vector-borne diseases forms complex systems in the landscape (Vanwambeke et al., 2011). These systems are influenced by a broad spectrum of environmental factors operating at diverse scales, including climate (Debien et al., 2009; Ben Ari et al., 2011), land cover (Lambin et al., 2010), soil, landscape and land use (Patz et al., 2004; Neerinckx et al., 2010; Vanwambeke et al., 2011; Ben Ari et al., 2011; Baumgardner et al., 2012; Chammartin et al., 2013). In Tanzania, plague (caused by Yersinia pestis) has occurred in West Usambara Mountains and in the Mbulu district since 1980 (Kilonzo \& Mhina, 1982; Kilonzo et al., 1997, 2005; Makundi et al., 2003, 2007, 2008; Laudisoit et al., 2009a,b; Neerinckx et al., 2010). Most of the data and analytical techniques in these studies concentrated on biological and microbiological factors for which, unlike in the current study, little or no appeal was made to detailed terrain and land cover data involving remote sensing and geographical information systems (GIS).

Coarse resolution remote sensing and GIS techniques have been widely applied to understand the relation of regionally distributed environmental factors in relation to vector borne diseases including malaria (Ceccato et al., 2005), dengue (Palaniyandi, 2012) and plague (Eisen et al., 2011, 2012; MacMillan et al., 2011). Debien et al. (2009) used Tropical Rainfall Measuring Mission (TRMM) at $0.25 \times 0.25 \mathrm{~km}$ resolution and MODIS monthly NDVI ( $1 \times 1 \mathrm{~km})$ data to reconstruct rainfall patterns at $1 \times 1 \mathrm{~km}$ resolution for predicting occurrence of plague in northeastern Tanzania. Neerinckx et al. (2010) used environmental dataset assembled from MODIS

\footnotetext{
Correspondence: Didas N. Kimaro; E-mail: didas kimaro@yahoo.com
} 
data at $250 \mathrm{~m}$ resolution to predict potential risk areas of human plague in the Lushoto area of Tanzania and in larger parts of East and Southern Africa. Eisen et al. (2010) and MacMillan et al. (2011), attempted to identify elevated risk of human exposure to plague bacteria at sub-village level, using SRTM DEM (90m), and Landsat $\mathrm{ETM}^{+}$(30×30m). Eisen et al. (2012) used 2-km resolution climate dataset derived from a suite of atmospheric simulations with the Weather Research and Forecasting Model (WRF) (Monoghan et al., 2012) to compare host and flea abundance and diversity along an elevation gradient performed specifically for the West Nile region plague focus in Uganda.

Land cover is an important determinant of habitat suitability for disease vectors and hosts (Linard et al., 2007) and hence of health risk hazards to humans. The abundance and spatial distribution of small mammals and fleas vary along the different land cover types and between landscape units (Vanwambeke et al., 2011). Higher resolution remote sensing data are of increasing interest in disease studies (Ostfeld et al., 2005); especially when land cover and landscape factors enter the picture. These factors also ask for spatial analytical tools and GIS. However, some factors including cost, access to equipment or insufficient skills in remote sensing and GIS have prohibited such approach (Le Sueur \& Martin, 1996; Tanser \& le Sueur, 2002; Ostfeld et al., 2005; Zhang et al., 2013). The objective of this study was therefore to refine the analysis of single and combined land cover and terrain characteristics in order to gain a better understanding of localised plague infection risks in the West Usambara Mountains in north-east Tanzania. It is expected to provide useful information for plague and other rodent borne disease control programmes as well as information for further in-depth research on the complex ecology of the plague system.

\section{Materials and Methods}

\section{Study area}

This study was carried out in the Western Usambara Mountains in Lushoto district of northeastern Tanzania. The study area is located between Universal Transverse Mercator (UTM) coordinates $4000000 \mathrm{~m} \mathrm{E}$ and $430000 \mathrm{~m} \mathrm{E}$ and between $9480000 \mathrm{~m} \mathrm{~N}$ and $9500000 \mathrm{~m} \mathrm{~N}$, Zone $37 \mathrm{M}$, covering an area of about 34,00oha (Figure 1). The altitude ranges from 480 to $2,271 \mathrm{~m}$. In the Western Usambara Mountains, two rainy seasons exist: short rains (vuli) from October to December and long rains (masika) from March to May (Debien et al., 2009). The rainy seasons are associated with the seasonal movement of the Intertropical Convergence Zone (ITCZ). Rainfall in the study area is influenced by topography (Debien et al., 2009). The rainy seasons are associated with the seasonal movement of the Intertropical Convergence Zone (ITCZ). Rainfall in the study area is influenced by topography (Debien et al., 2009). The area has mean annual precipitation ranging from 600 to $1200 \mathrm{~mm}$. The study area shows large differences in relief dissection and intensity, vegetation and land use patterns, and human activities. Land use is dominated by mixed rainfed farming, followed by irrigated agriculture, livestock keeping and off farm activities including petty cash and carpentry (Msita et al., 2010). These land uses are bordered or surrounded by natural forests, and plantation forest and utility woodlots.

Previous research on rodents, fleas and plague (Njunwa et al., 1989; Kilonzo et al., 1997; Davis et al., 2006; Kamugisha et al., 2007; Laudisoit et al., 2007, 2009a, b; Neerinckx et al., 2010) allowed defining the study area in such a way that it reflects a geographical gradient in the frequency of plague incidence. These authors concur in distinguishing high, medium, and low incidence zones. Within this gradient three representative landscapes were selected differing in terms of (i) the incidence of plague, (ii) diversity in land use and associated human activities, (iii) landform characteristics (relief intensity and level of dissection), and (iv) climatic conditions. The selected landscapes are named Shume (high plague incidence), Lukozi (medium plague incidence) and Mwangoi (low plague incidence) landscapes, after the name of their most important settlement. 


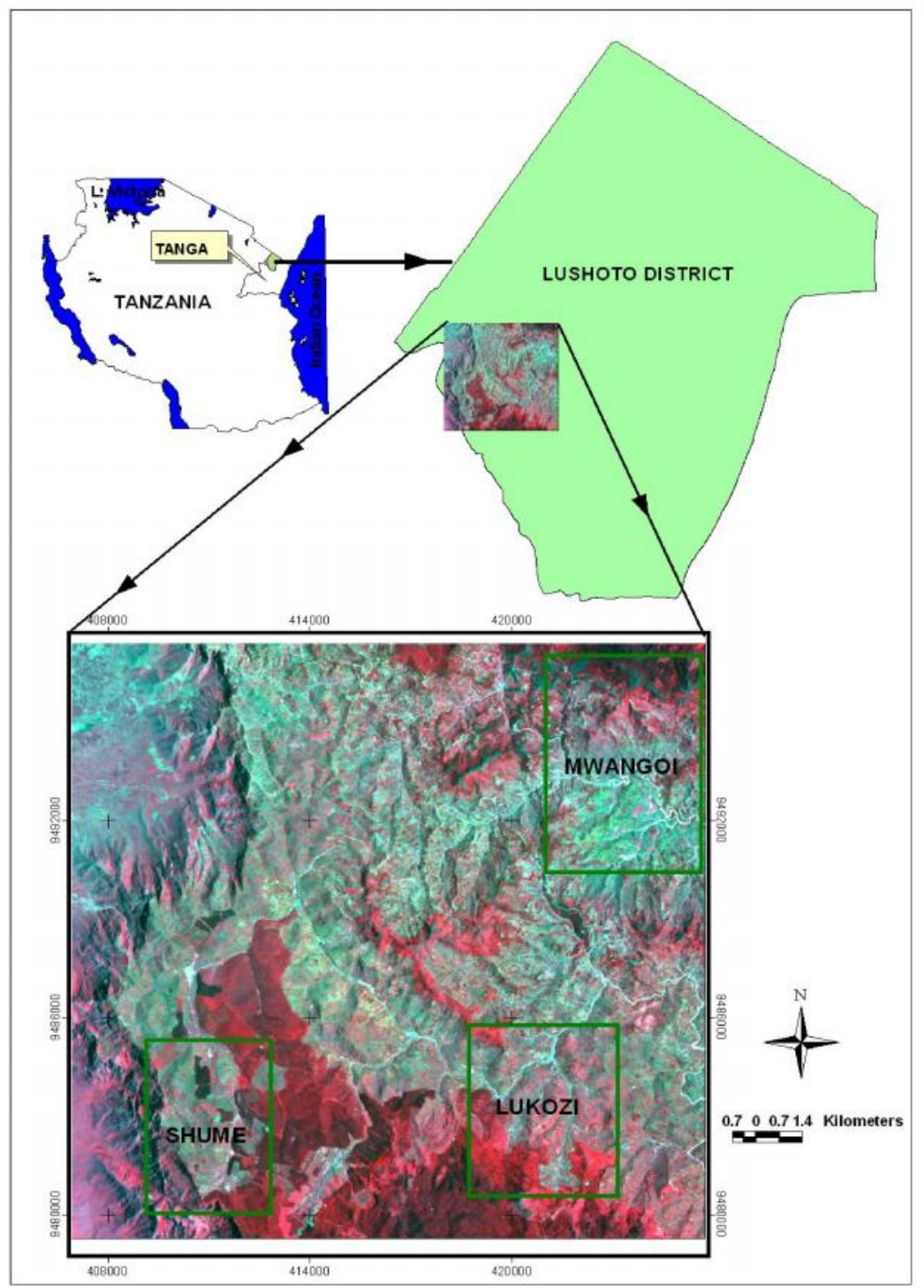

Figure 1: Selected study landscapes in West Usambara Mountains, Tanzania

\section{Data collection and analysis}

This study included the generation of terrain attributes from Advanced Spaceborne Thermal Emission and Reflection Radiometer (ASTER) Digital Elevation Model (DEM) with 30m resolution, a land cover map from three-band SPOT 5 image (nominal spatial resolution $2.5 \mathrm{~m}$ ) and the collection of small mammals and fleas. Boosted Regression Trees (BRT) was used to identify terrain and land cover predictors of abundance of small mammals and fleas. Both categories of organisms are seen as indicators of potential plague occurrence at landscape scale. The final layers were saved in raster (geotiff) format. Land cover was also defined in vector (shapefile) format. Data extraction and zonal statistics were carried out in ARCGIS 9.3 and QGIS respectively to generate spatial and attribute data for each 100x100m quadrat in which small mammals and fleas were collected. The developed spatial geodatabase associated with their attributes were used as independent variables in BRT analysis. Small mammal and flea data were used as dependent variables.

The developed geospatial database can be used in desktop GIS with ARCGIS, ARCVIEW, QGIS and other related GIS software. The methodological flow chart (Figure 2) summarises the steps followed in spatial geodata capturing, processing, integration, storage, and BRT modelling. 


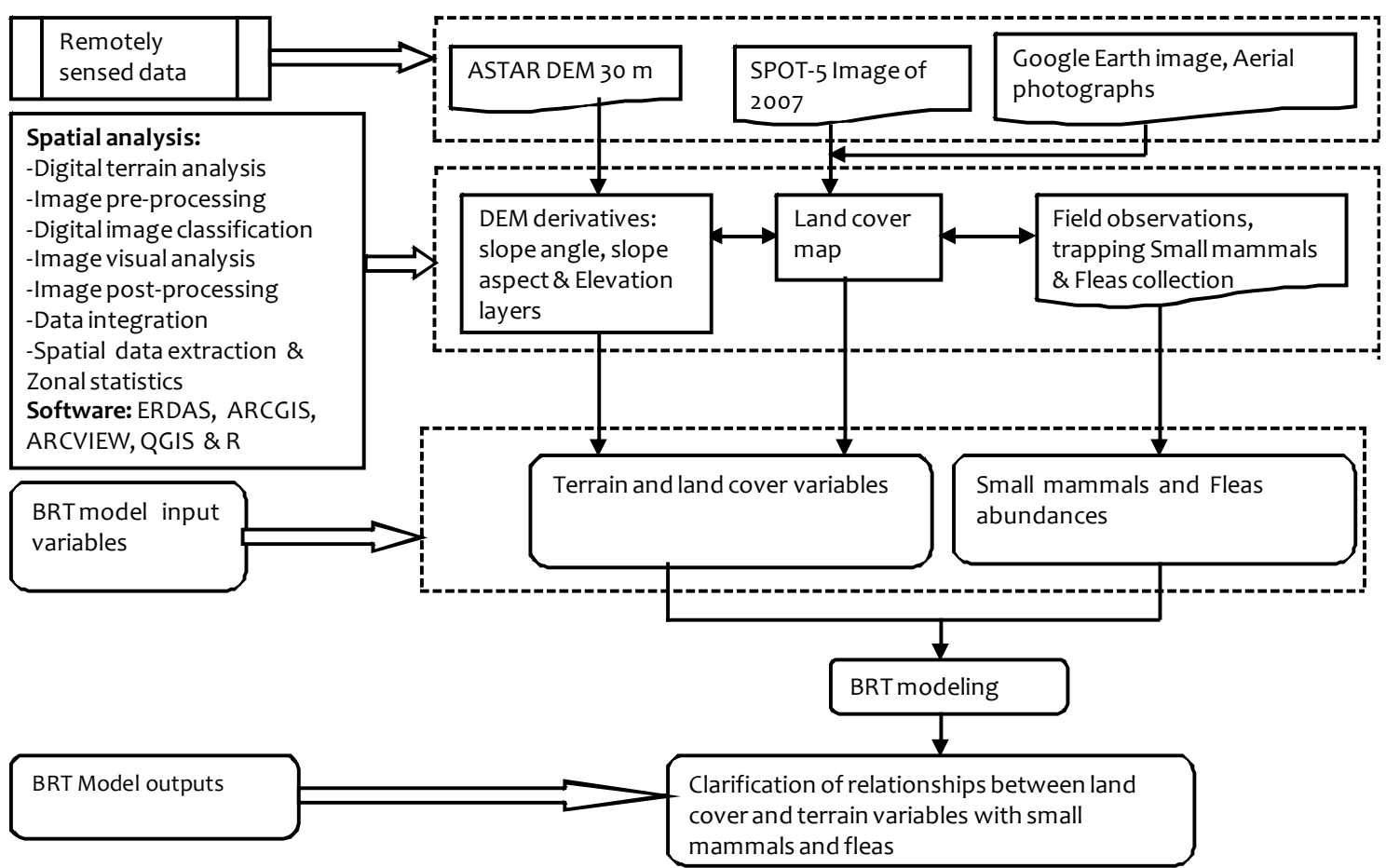

Figure 2: Methodological flow chart summarising the steps followed for data collection and analysis

\section{Mapping of terrain variables}

Three topographical variables (elevation, slope gradient and slope aspect) were derived from the ASTER DEM (30m) using ARCGIS 9.3 software. Elevation strongly determines climate in this area. Slope gradient strongly influences the choice of land management types, and is correlated with soil characteristics (Msita et al., 2010). Slope aspect, measured clockwise in degrees from 0 (north) to 360 , has been reported to influence rainfall in the West Usambara Mountains (Kajembe, 1994). Flat areas are given a slope aspect value of -1 .

\section{Generation of a land cover map}

A cloud free three-band SPOT 5 image captured on 27 February 2007, nominal spatial resolution $2.5 \mathrm{~m}$, was used in this study. The image was orthorectified in ERDAS 2011 software. The initial classification of land cover was based on 20 spectral classes generated using the unsupervised ISODATA clustering technique in ERDAS2011. GPS supported field observation was conducted in August to September 2011, April to June 2012 and in August to October 2012, and allowed to define characteristic tone, texture and pattern of the land cover classes on the display of the SPOT 5 colour composite image. Also aerial photographs and Google Earth provided essential independent reference data to help in identifying land cover types within the SPOT 5 image.

The description of the different land cover categories was in the first instance based on Anderson et al. (1976) and then refined to match the terminology of the FAO Guidelines for Soil Description (FAO, 2006). Because of the occurrence of mixed pixels, similarity in spectral signatures of some land cover types, and heterogeneous illumination conditions in this undulating area, a hybrid image classification method was used (Wang et al., 2005; Horning, 2010a). This approach combines the advantages of the automated and manual methods to produce land cover maps (Horning, 2010a). Expert information and visual interpretation allowed refining and correcting the automated classification (Horning, 2010a). Also existing information, for example on the location and extent of plantation forest, was directly inserted in the land cover map, to avoid confusing recently harvested patches with bare land. 
Supervised classification was done using Random Forest (RF) algorithm (Breiman, 2001) in R software ( $R$ Development Core Team, 2006). Random Forest is known to be one of the most efficient classification methods (Akar \& Gungor, 2012). A script written by Horning (2010b) was used. The script requires that training areas are digitized as polygons and saved as an ESRI shapefile. The training dataset is defined as multiple polygons for each class.

Post-processing of classified image included majority neighbourhood filter, clump and eliminate. The classified map was later compared with the original image and reference data used in this study. Classes which were not labelled correctly were spotted and edited. Five classes out of twelve were successfully generated: Cropland (Rainfed maize and beans), Agroforestry, Settlement, Woodlot and Shrub. Seven out of twelve classes were not sufficiently well classified by this algorithm due to similarity in spectral signatures: Cropland (perennials and furrow irrigated vegetables), Cropland (supplemental irrigated vegetables and potatoes), plantation forest, natural forest, grassland with emergent trees, bushland and woodland. Their initial classification was corrected through onscreen digitisation after visual interpretation of the SPOT 5 image. Software used during pre and post processing of the classified SPOT 5 image includes Arc View 3.3, ARCGIS 9.3 and ERDAS 2011.

\section{Collection of data on small mammals and fleas}

Based on the land cover and terrain attributes generated above, a total of 72 quadrats of $100 \times 100$ $\mathrm{m}$ were established. Twenty four quadrats were established at random for each landscape. At each observation site (quadrat) data on land cover, rodents and fleas from rodents were collected. Data collection was conducted in the dry season (August to October) of 2012.

Small mammals were trapped using Sherman LFA live traps $(7.5 \times 9.0 \times 23 \mathrm{~cm}$; HB Sherman Traps, Tallahassee, USA) baited with peanut butter and maize flour. A total of 49 Sherman live traps spaced $10 \mathrm{~m}$ apart were set in a grid per observation site (quadrat) and per trapping session. For the sites in natural forests, additionally two wire cages were used to capture somewhat larger mammals like squirrels. Each trapping session lasted 3 nights. Each trap was inspected every morning and traps with captured animals were replaced by empty traps (Zimba et al., 2011). The captured animals were identified to genus level or species level where possible (Eisen et al., 2012) and carefully combed for fleas. Trap success (in percent) was calculated as the number of small mammals captured multiplied by 100 divided by the trap nights (i.e. number of traps $x$ number of days) per quadrat (Mulungu et al., 2008; Laudisoit et al., 2009a). Fleas collected from each small mammal were counted. The flea index was calculated as the total number of fleas per total number of captured mammals in each quadrat (Laudisoit et al., 2009a). Trap success and flea index were used as dependent variables in the Boosted Regression Tree (BRT) modelling (to be explained later).

\section{Boosted Regression Tree modelling}

Exploring plague disease infection risk patterns requires a statistical technique that effectively addresses the complexity of the landscape systems and the disease ecology (Skolow et al., 2009; Williams et al., 2010; Aertsen et al., 2012). The Boosted Regression Tree (BRT) model in R software ( $R$ Development Core Team, 2006) was used in this case. Models were fitted using the gbm.step function and a Gaussian response type, with most effective settings for learning rate (0.010.00001 ) and bag fraction (0.5-0.75) as found by repeated trial-and-error (Elith et al., 2008). Tree complexity was set to 3, according to recommendations by Elith et al. (2008) for small datasets. The 10-fold cross-validation (CV) was used for model development and validation, with the benefit of still using the full data set to fit the final model (Elith et al., 2008). The measure of model performance was cv deviance and standard error (Elith et al., 2008; Williams et al., 2010). The combination of learning rate and bag fraction settings with the lowest $c v$ deviance and standard error was the one selected to produce the final BRT model (Williams et al., 2010). Also during data exploration all predictor variables were tested for ecologically acceptable level of 
collinearity (i.e. individual variance inflation factor (VIF) of $<5$ ) between predictor variables (Zuur et al., 2010; Artsen et al., 2012).

\section{Ethical considerations}

This study received approval from Directorate of Research and Post-Graduate Studies of Sokoine University of Agriculture, Tanzania and Flemish Inter-University Council (VLIR-UOS) of Belgium.

\section{Results}

\section{Land cover, terrain variables and small mammals}

Figure 3A presents the land cover types of 2012 while in Table 1 their respective dominant coverage for the three studied landscapes are given. Figures $3 \mathrm{~B}, 4 \mathrm{~A}$ and $4 \mathrm{~B}$ present elevation ranges, slope aspect and slope angle respectively, which are terrain attributes used as predictor variables along with land cover types for prediction of small mammal and flea abundance and spatial distribution. Table 2 provides the summary of the values for the terrain attributes extracted from the ASTER DEM and small mammal and flea abundances.

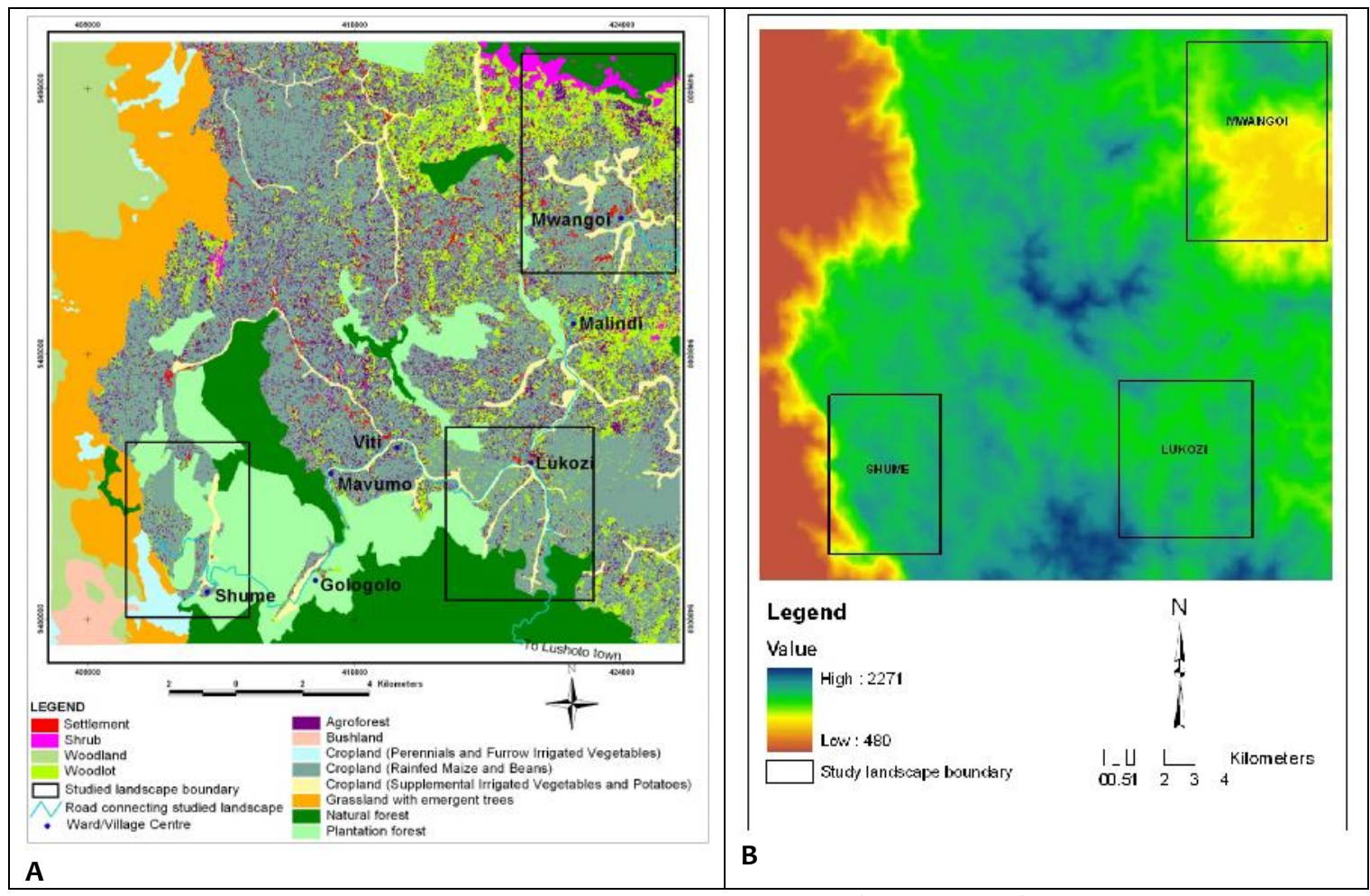

Figure 3 A: Land cover map covering the three studied landscapes (inside boxes); B: Elevation ranges used as terrain predictor variable for small mammal and flea abundance 
Table 1: Land cover categories of the studied landscapes

\begin{tabular}{|c|c|c|c|}
\hline \multirow[t]{2}{*}{ Land cover (ha) } & \multicolumn{3}{|c|}{ Landscape } \\
\hline & Mwangoi & Lukozi & Shume \\
\hline Agroforest & $277.1(9.1 \%)$ & $83.6(3.6 \%)$ & $35.9(1.8 \%)$ \\
\hline Cropland (Rainfed Maize and Beans) & $1229.5(40.3 \%)$ & $1169.8(50.9 \%)$ & $445.5(22.9 \%)$ \\
\hline Cropland (Irrigated Vegetables and Potatoes) & $207.9(6.8 \%)$ & $122.6(5 \cdot 3 \%)$ & $59.9(3.1 \%)$ \\
\hline Natural forest & $330.3(10.8 \%)$ & $509.4(22.1 \%)$ & $107.9(5.6 \%)$ \\
\hline Plantation forest & $48.3(1.6 \%)$ & $233.3(10.1 \%)$ & $857.4(44.2 \%)$ \\
\hline Shrub & $194.9(6.4 \%)$ & $3.2(0.1 \%)$ & $2.1(0.1 \%)$ \\
\hline Woodlot & $684.2(22.5 \%)$ & $161.9(7.0 \%)$ & $32.7(1.7 \%)$ \\
\hline Settlement & $74.8(2.5 \%)$ & $16.1(0.7 \%)$ & $4.4(0.2 \%)$ \\
\hline Woodland & & & $30.6(1.6 \%)$ \\
\hline $\begin{array}{l}\text { Cropland (Perennials and Furrow Irrigated } \\
\text { Vegetables) }\end{array}$ & & & $185.8(9.6 \%)$ \\
\hline Grassland with emergent trees & & & $171.5(8.8 \%)$ \\
\hline Bushland & & & $7.4(0.4 \%)$ \\
\hline Total & $3,047.1$ & $2,300.0$ & $1,941.1$ \\
\hline
\end{tabular}

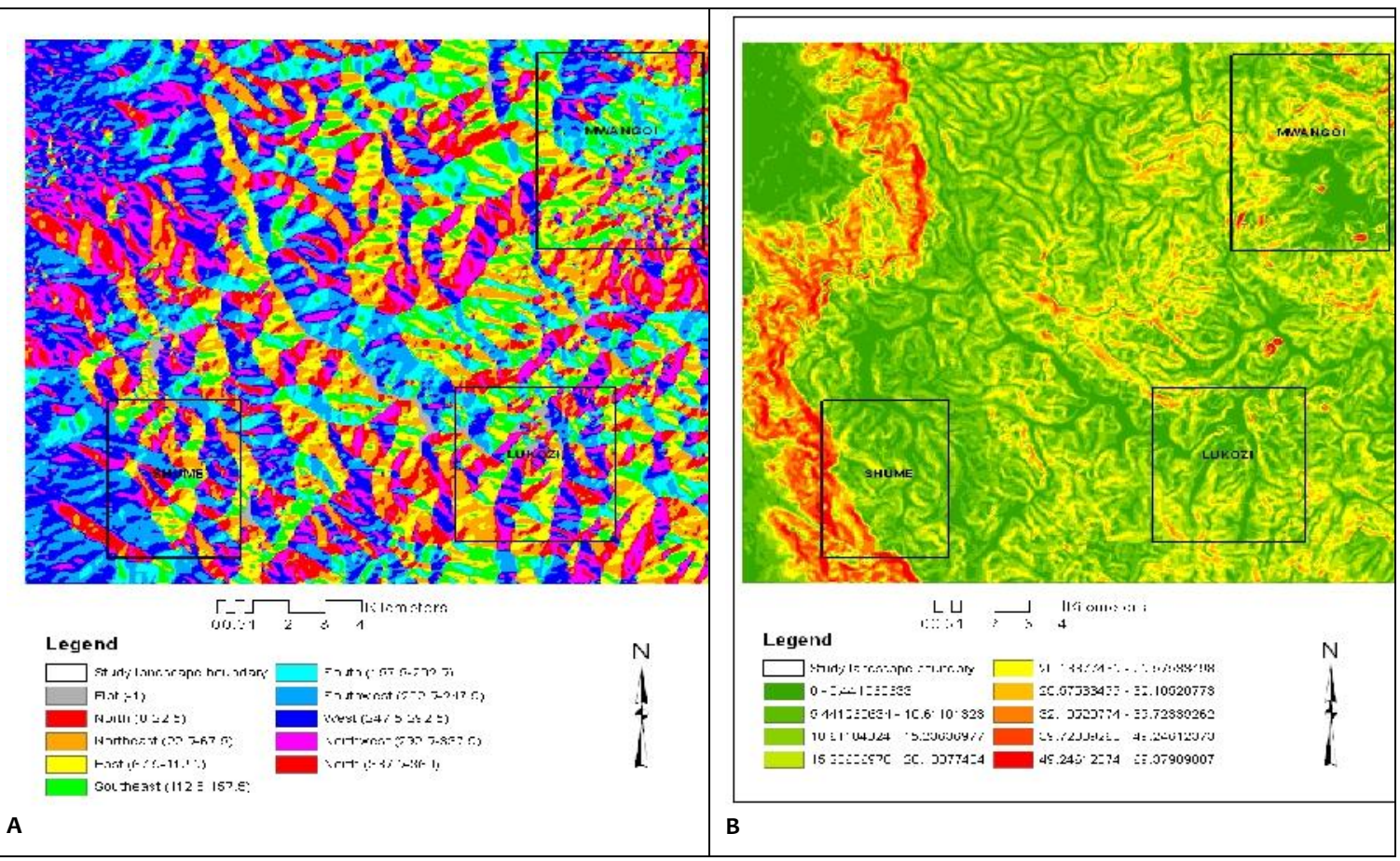

Figure 4 A: Slope aspects used as terrain predictor variable; and B: Slope angle in degrees used as predictor variable for small mammals and fleas abundance

Table 2: Summary of the terrain attributes values and small mammals and fleas

\begin{tabular}{lllll}
\hline Landscape & Attribute & Attribute Mean & Small mammals & Fleas \\
\hline Mwangoi & Elevation (m) & 1589 & $79(14 \%)$ & $137(20 \%)$ \\
& Slope angle (deg) & 13.8 & & \\
Lukozi & Slope aspect (deg) & 163.3 & & \\
& Elevation (m) & 1855 & $232(40 \%)$ & $180(27 \%)$ \\
Shume & Slope angle (deg) & 12.7 & & $358(53 \%)$ \\
& Slope aspect (deg) & 169 & $265(46 \%)$ & \\
& Elevation (m) & 1819 & & \\
\hline
\end{tabular}


Boosted Regression Trees (BRT) model for explaining the relationship between land cover, terrain attributes and small mammals

Four predictor variables were retained by the BRT model as being influential on the observed spatial pattern of trap success (Figure 5). All four predictor variables had the ecologically acceptable level of individual variance inflation factor i.e. VIF $<5$. Elevation was the most important predictor with contribution of more than two thirds of the total (80.1\%) and a strong positive effect. The elevation of $1,700 \mathrm{~m}$ appeared to be the threshold for a sharp increase in trap success. The second important predictor was slope aspect with contribution of $11.4 \%$ and a moderate positive effect. The location on 150 degree aspect (south east facing slope) appeared to be an important condition for increased trap success. The slope angle and land cover had weak positive effect although with small contributions. The abundance of small mammals (trap success) seemed to increase slightly on slopes of 10 degrees and above. The abundance also gradually increased as the land cover types varied from natural forest (coded 1) to other land cover types (coded from 2 to 7 ).
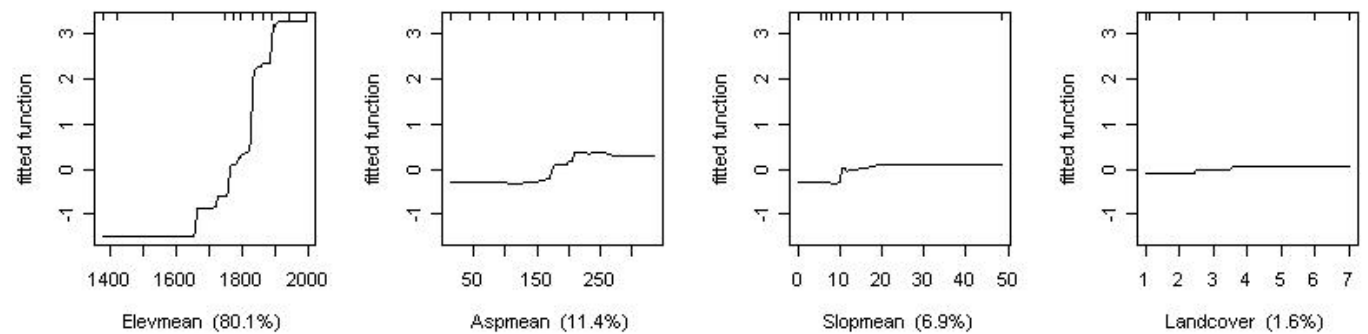

Figure 5: Partial dependence plots showing the effect of land cover \& terrain variables on spatial pattern of small mammals. The relative contribution of each predictor is given in brackets. CV deviance $=22.343$, standard error=3.612, number of trees=1250. Key: Elevmean = Elevation, aspmean = Slope aspect, slopmean = Slope angle, Landcover $=$ Land cover)

\section{BRT model for explaining the relationship between land cover, terrain attributes and fleas}

Four predictor variables were identified by the BRT model as having influence on the observed spatial pattern of flea index (Figure 6). All four predictor variables had the ecologically acceptable level of individual variance inflation factor i.e. $\mathrm{VIF}<5$. Slope angle was the most important predictor with contribution of more than two thirds of the total (75.3\%) and a strong positive effect. The presence of a slope angle of at least 10 degrees appeared to be an important condition for increased rodent flea abundance (flea index). The second important predictor was elevation with contribution of $17.3 \%$ and a moderate positive effect. The elevation of $1800 \mathrm{~m}$ appeared to be an important condition for increased flea index. Land cover and slope aspect had smaller contributions and showed weak effect. Land cover showed a slight negative effect as land cover types varied from that dominated by natural forest (coded 1) and plantation forest (coded 2) to the rest of the land cover types (coded from 3 to 7 ) (Figure 6).
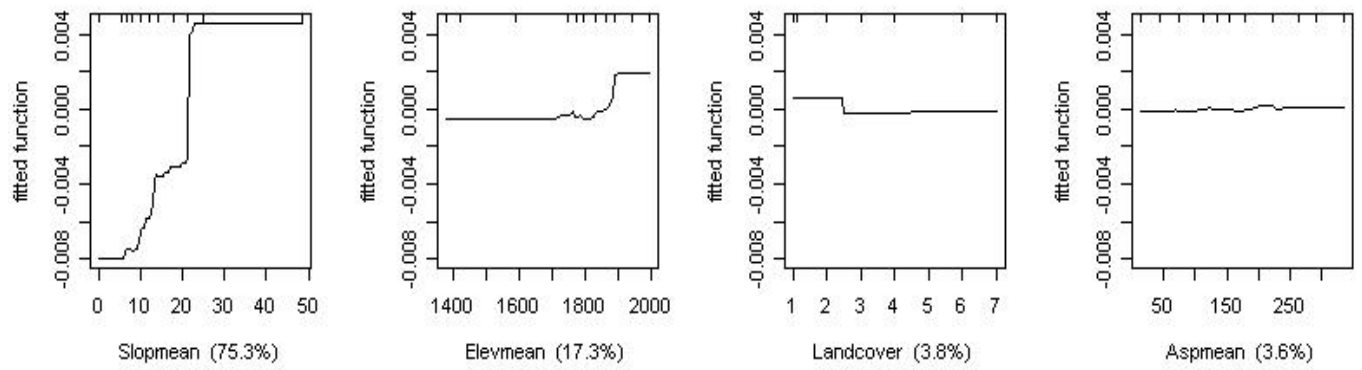

Figure 6: Partial dependence plots showing the effect of land cover and terrain variables on spatial pattern of flea index. The relative contribution of each predictor is given in brackets. Key $=C V$ deviance $=1.764$, standard error=0.561, number of trees=1000. Key: Elevmean = Elevation, aspmean = Slope aspect, slopmean = Slope angle, Landcover $=$ Land cover) 


\section{Discussion}

Small mammals trap success seems to be greatly influenced by altitude. This finding is contrary to the observations by Mulungu et al. (2008) who found a decrease in small mammals trap success with altitude along Mount Kilimanjaro in Tanzania. This could be attributed to the increased resource availability (water and food) as one moves from low to high altitude in the studied landscapes compared to Mount Kilimanjaro, where resources availability decreases with increase in altitude. Furthermore, the results of our study clearly demonstrate that there is a positive influence of slope aspect on the small mammals trap success in the range 112-157 degrees i.e. south east facing slopes. This could be due to availability of water for small mammals as a result of orographic effect. High rainfall in West Usambara Mountains occurs in areas located to the east and south east which are the first to receive moisture-laden south-easterly trade winds from the Indian Ocean (Kajembe, 1994). The findings of this study are consistent with earlier studies which reported that food, water, rainfall and shelter are important factors for small mammals' abundance (Mwanjabe, 1993; Makundi et al., 2007; Mulungu et al., 2011).

The current study shows that slope gradient has strong positive influence on flea index. This relationship could be attributed to the different land management types and crops found on different geographic locations across the studied landscapes. The valley bottom areas and foot slopes characterized by flat or gentle slopes are mostly under irrigated vegetables. The application of insecticides and pesticides may explain the very low flea indices. As slope increases from lower parts to middle and upper slopes rainfed agriculture (i.e. the land cover type described in the current study as cropland (rainfed maize and beans) becomes the dominant land use. Also intensive land management practices including contour farming and indigenous land management system with grassy hedges called miraba increase. According to another study in the same area (Msita et al., 2011), the density of miraba (total length of miraba segments per unit area) increases with slope gradient. Therefore, this strong positive influence of slope angle on flea index could be attributed to land management practices and mainly miraba cultivation which are associated with many rodent burrows (Kamugisha et al., 2007; Brabers, 2012).

It should be noted that rodent burrows are also likely to harbour adult 'free flea population' which sometimes stay off host in the burrows (Eisen et al., 2012). According to Eisen et al. (2012), it is possible that off host adult flea populations of some infected species are able to survive for relatively long periods in burrows or nests, thus contributing to chances of plague persistence. Since the miraba in the study area provide suitable habitats for rodents, the possibility of rodents contacting high numbers of fleas inside burrows is most likely to be high (Hubbart et al., 2011). The grasses grown along miraba can be a hiding place for pests like rats (Kamugisha et al., 2007; Msita et al., 2011). Miraba planted with Guatemala and elephant grass are frequently visited by humans during the dry season for fodder collection, a common practice for farmers practising zero grazing, hence high chances of flea bites (Vanwambeke et al., 2011). Also natural forests and shrubs on rocky slopes in the area mostly found on upper slopes and ridges also favour rodents' and fleas' abundance. These observations support earlier suggestions of potential plague infection risks being associated with land management and farming practices during epizootic periods in the plague risk area (MacMillan et al., 2011; Zimba et al., 2011).

In this study, flea index also tended to decrease as land cover types varied from natural forest and plantation forest to other classes. Results suggest that land cover dominated by natural forest and plantation forest tended to favour more fleas than other land cover types, though with weak effect. The effect of land cover type on flea abundance was reported in earlier studies in the study area (Laudisoit et al., 2009a, b). In these studies shrubs which are also present in forested zones, were reported to have the highest flea abundance levels when compared to the other land cover types. Furthermore, elevation showed strong positive influence on flea index especially above $1800 \mathrm{~m}$. These findings are in line with previous studies in 
the study area and elsewhere (Kilonzo et al., 1992, 2005; Pham et al., 2009; Winters et al., 2009; Neerinckx et al., 2010).

The middle and upper slopes of the study area dominated by miraba land management practices and contour farming favour the abundance of fleas. In addition, elevations above 1800 $\mathrm{m}$ have a strong positive influence on flea index. Furthermore, elevation has a strong positive relation with small mammals trap success, which can be explained by an increase of food and water availability with altitude. Land cover and terrain variables influence and predict the spatial distribution of small mammals and fleas abundance across the West Usambara Mountain landscapes.

The relationship between land cover and terrain attributes on one hand and small mammals and fleas as potential hosts and vectors of plague, hence as indicators of plague risks, on the other hand has been well elaborated by remote sensing and GIS integration of geodatabase at different spatial scales and resolutions. This has revealed that a geomatic approach using remote sensing data and GIS technologies is valuable in studying plague infection risks.

The developed spatial geodatabase is structured for easy access and use on desktop computer GIS. The framework developed by this study forms a useful tool for plague surveillance and to inform communities on the probable risks associated with various landscape factors during epidemics. The framework is also a powerful tool for land and pest management including management of rodents which are dominantly crop pests. The geodataset derived from the satellite data including land cover, and DEM derivatives integrated in the expert GIS engine provide future potential analysis and understanding of the association of plague risk indicators including climate and human behaviour variables. In addition the developed geodatabase is vital information for district land use planning and rural development programmes in the study area.

\section{Acknowledgements}

This work was supported by the Sokoine University of Agriculture - Flemish Interuniversity Council (SUA-VLIR) Own Initiative Project - 'Landscape-Ecological Clarification of Bubonic Plague Distribution and Outbreaks in the West Usambara Mountains, Tanzania' (Acronym: LEPUS), funded by the Flemish Interuniversity Council (VLIR), Belgium. The authors greatly appreciate the assistance of Dr. Wim Aertsen of KU Leuven for BRT modelling. Many people including farmers in the study area, staff of Lushoto District Council and Sebastian Kolowa Memorial University are thanked for the cooperation and enthusiasm.

\section{References}

Anderson, J.R., Hardy, E.E., Roach, J.T. \& Wither, R.E. (1976) A Land Use and Land Cover Classification System for Use With Remote Sensor Data. Geological survey Professional Paper 964: 36p.

Aertsen, W., Kint, V., Vos Bruno, D., Deckers, J., Van Orshoven, J. \& Muys, B. (2012) Predicting forest site productivity in temperate lowland from forest floor, soil and litterfall characteristics using boosted regression trees. Plant Soil 354, 157-172.

Akar, O. \& Gungor, O. (2012) Classification of multispectral images using Random Forest algorithm. Journal of Geodesy and Geoinformation 105-112.

Baumgardner, D.J. (2012) Soil related bacterial fungal infections. Journal of American Board of Family Medicine 25, 734-744.

Ben Ari, B.T., Neerinckx, S., Gage, K.L., Kreppel, K., Laudsoit, A., Leirs, H. \& Stenseth, N. (2011) Plague and Climate: Scale Matter. PLoS Pathogens 7(9), e1002160. 
Brabers, L. (2012) Land Characteristics, Soil Properties and Microclimate Associated with Rodent Burrows in a Selected Plague Focus, Lushoto District, Tanzania. MSc Dissertation, K.U.Leuven, Belgium. 71pp.

Breiman, L. (2001) Random forests. Machine Learning 45, 5-32.

Ceccato, P., Connor, S.J., Jeanne, I. \& Thomson, M.C. (2005) Application of Geographical Information Systems and Remote Sensing Technologies for assessing and monitoring malaria risk. Parassitologia 47, 81-96.

Charmmartin, F., Scholte, R.C.G, Malone, J.B, Bavia, M.E, Nieto, P., Utzinger, J. \& Vounatsou, P. (2013) Modelling the geographical distribution of soil-transmitted helminth infections in Bolivia. Parasites \& Vectors 6, 152.

Davis, S., Makundi, R.H., Machang'u R.S., \& Leirs, H. (2006) Demographic and spatio-temporal variation in human plague at a persistent focus in Tanzania. Acta Tropica 100, 133-141.

Debien, A., Neerinckx, S., Kimaro, D. \& Gulinck, H. (2010) Influence of satellite-derived rainfall patterns on plague occurrence in northeast Tanzania. International Journal of Health Geographics 9, 60.

Eisen, L. \& Eisen, R.J. (2011) Using geographic information systems and decision support systems for the prediction, prevention, and control of vector-borne diseases. Annual Review of Entomology 56, 41-61.

Eisen, R.J., Borchert, J.N., Mpanga, J.T., Atiku, L.A., MacMillan, K., Boegler, K.A., Montenieri, J.A., Monaghan, A. \& Gage, K.L. (2012) Flea diversity as an element for persistence of plague bacteria in an East African plague focus. PLoS One 7 (4), e35598.

Elith, J., Leathwick, J.R. \& Hastie, T. (2008) A working guide to boosted regression trees. Animal Ecology 77, 802-813.

FAO (2006) Guidelines for soil description. Food and Agriculture Organisation, Viale delle Terne di Caracalla, Rome, 110p.

Horning, N. (2010a) Land covers classification methods. American Museum of Natural History, Center for Biodiversity and Conservation. http://biodiversityinformatics.amnh.org. Accessed on 28.04.2014.

Horning, N. (2010b) Training Guide for Using Random Forests to Classify Satellite Imgaes. American Museum of Natural History, Center for Biodiversity and Conservation. http://biodiversityinformatics.amnh.org. Accessed on 28.04.2014.

Hubbart, J.A., Jachowski, D.S. \& Eads, D.A. (2011) Seasonal and among-site variation in the occurrence and abundance of fleas on California ground squirrels (Otospermophilus beecheyi). Journal of Vector Ecology 36, 117-123.

Kajembe, C.G. (1994) Indigenous Management Systems as a Basis for Community Forestry in Tanzania: A Case Study of Dodoma Urban and Lushoto Districts. PhD Thesis, Wageningen Agricultural University, The Netherlands, 194pp.

Kamugisha, M.L., Gesase, S., Minja, D., Mgema, S., Mlwilo, T.D., Mayala, B.K., Msigwa, S., Massaga, J.J. \& Lemnge, M.M. (2007) Pattern and spatial distribution of plague in Lushoto, north-eastern Tanzania. Tanzania Health Research Bulletin 9, 12-18.

Kilonzo, B., Mhina, J., Sabuni, C. \& Mgode, G. (2005) The role of rodents and small carnivores in plague endemicity in Tanzania. Belgian Journal of Zoology 135, 119-125.

Kilonzo, B.S. \& Mhina, J.I. (1982) The first outbreak of human plague in Lushoto district, northeast Tanzania. Transactions of the Royal Society of Tropical Medicine and Hygiene 76, $172-177$.

Kilonzo, B.S., Mvena, Z.S.K., Machangu, R.S. \& Mbise, T.J. (1997) Preliminary observations on factors responsible for long persistence and continued outbreaks of plague in Lushoto district, Tanzania. Acta Tropica 68, 215-227.

Lambin, E.F., Tran, A., Vanwambeke, S.O., Linard, C. \& Soti, V. (2010) Pathogenic landscapes: Interactions between land, people, disease vectors and their hosts. International Journal of Health Geographics 9, 54. 
Laudisoit, A., Leirs, H. , Makundi, R.H. \& Krasnov, B. (2009a) Seasonal and habitat dependence of fleas parasitic on small mammals in Tanzania. Integrative Zoology 4, 196-212.

Laudisoit, A., Leirs, H., Makundi, R.H., Van Dongen, S., Davis, S., Neerinckx, S., Deckers, J. \& Libois, R. (2007) Plague and the human flea, Tanzania. Emerging Infectious Diseases $13,687-693$.

Laudisoit, A., Neerinckx, S., Makundi, R.H., Leirs, H. \& Krasnov, B. (2009b) Are local plague endemicity and ecological characteristics of vectors and reservoirs related? A case study in north-east Tanzania. Current Zoology 55, 199-211.

Le Sueur, D. \& Martin, C. (1996) Regional and Continental Initiatives in Malaria Control. Proceedings of the Seventh International Symposium in Medical Geography. Portsmouth, July 30 - August 2, 1996. 184-186.

Linard, C., Lamarque, P., Heyman, P., Ducofftre, G., Luyasu, V., Tersago, K., Vanwambeke, O.S. \& Lambin, E.F. (2007) Determinants of the geographic distribution of Puumala virus and Lyme borreliosis infection in Belgium. International Journal of Health Geographics $6,15$.

Makundi, R.H., Kilonzo, B.S. \& Massawe, A.W. (2003) Interaction between rodent species in agroforestry habitats in the Western Usambara Mountains, north-eastern Tanzania, and its potential for plague transmission to humans. G.R. Sigleton, ed. Rats, Mice and People: Rodent Biology and Management. Australian Centre for International Agricultural Research, Canberra, 20-24p.

Makundi, R.H., Massawe, A.P., Mulungu, L.S., Katakweba, A., Mbise, T.J. \& Mgode, G. (2008) Potential mammalian reservoirs in a bubonic plague outbreak focus in Mbulu District, northern Tanzania, in 2007. Mammalia 72, 253-257.

Makundi, R.H., Massawe, A.W. \& Mulungu, L.S. (2006) Breeding seasonality and population dynamics of three rodent species in the Magamba Forest Reserve, Western Usambara Mountains, north-east Tanzania. African Journal of Ecology 45, 17-21.

Makundi, R.H., Massawe, A.W. \& Mulungu, L.S. (2007) Reproduction and population dynamics of Mastomys natalensis Smith, 1834 in an agricultural landscape in the Western Usambara Mountains, Tanzania. Integrative Zoology 2, 233-238.

MacMillan, K., Enscore, R.E., Ogen-Odoi, A., Borchert, J.N., Babi, N., Amatre, G., Atiku, L.A., Mead, P.S., Gage, K.L. \& Eisen, R.J. (2011) Landscape and Residential Variables Associated with Plague-Endemic Villages in the West Nile Region of Uganda. American Journal of Tropical Medicine and Hygiene 84, 435-442.

Monaghan, A.J., MacMillan, K., Moore, S.M., Mead, P.S., Hayden, M.H. \& Eisen, R.J. (2012) A regional climatography to support human plague modeling in West Nile, Uganda. Journal of Applied Meteorology and Climatology 51, 1201-1221.

Msita, H.B., Kimaro, D.N., Deckers, J. \& Poesen, J. (2010) Identification and Assessment of Indigenous Soil Erosion Control Measures in the Usambara Mountains, Tanzania. Chapter 3 in Earl T. Nardal (Editor). No-Till Farming: Effects of Soil, Pros and Cons and Potential. Agriculture Issues and Policies Series. ISBN: 978-1-60741-402-5. Nova Science Publishers Inc, New York: 49-74.

Msita, H.B., Kimaro, D.N., Kihupi, N.I., Dondyene, S., Msanya, B.M., Mtakwa, P.W., Poesen, J. \& Deckers, J. (2011) Evolution of Miraba: An Indigenous Soil Erosion Control Technology in the Western Usambara Mountains, Tanzania. Paper presented to the International congress on: Integrated water-resources management in tropical and subtropical dry lands held at Mekelle, Ethiopia from 19-26 September 2011.

Mulungu, L.S., Mahlaba, T.A., Massawe, A.W., Kennis, J., Crauwels, D., Eiseb, S., Monadjem, A., Makundi, R.H., Katakweba, A.A.S., Leirs, H. \& Belmain, S,R. (2011) Dietary differences of the multimammate mouse, Mastomys natalensins (Smith, 1834), across different habitats and seasons in Tanzania and Swaziland. Wildlife Research 38, 640-646. 
Mulungu, L.S., Makundi, R.H., Massawe, A.W., Machang'u, R.S. \& Mbije, N.E. (2008) Diversity and distribution of rodent and shrew species associated with variation in altitude on Mount Kilimanjaro, Tanzania. Mammalia 72, 178-185.

Mwanjabe, P.S. (1993) The role of weeds on population dynamics of Mastomys natalensis in Chunya (Lake Rukwa) valley. In: Economic Importance and Control of Rodents in Tanzania, (ed.) S. Machang'u, pp. 34-42. Sokoine University of Agriculture, Morogoro.

Neerinkx, S., Peterson, A.T., Gulinck, H., Deckers, J., Kimaro, D. \& Leirs, H. (2010) Predicting potential risk areas of human plague for the Western Usambara Mountains, Lushoto District Tanzania. American Journal of Tropical Medicine and Hygiene 82, 492-500.

Njunwa, K.J., Mwaiko, G.L., Kilonzo, B.S. \& Mhina, J.I. (1989) Seasonal patterns of rodents, fleas and plague status in the Western Usambara Mountains, Tanzania. Medical and Veterinary Entomology 3, 17-22.

Ostfeld, R.S., Glass, G.E. \& Keesing, F. (2005) Spatial epidemiology: an emerging(or re-emerging) discipline. Trends in Ecology and Evolution 20, 328-336.

Palaniyadi, M. (2012) The role of Remote Sensing and GIS for spatial prediction of vector-borne diseases transmission: A systematic review. Journal of Vector Borne Diseases 49, 194204.

Patz, J.A., Graczyk, T.K., Geller, N. \& Vittor, A.Y. (2000) Effects of environmental change on emerging parasitic diseases. International Journal of Parasitology 30, 1395-1405.

Pham, H.V., Dang, D.T., Minh, N.T., Nguyen, N.D. \& Nguyen, T.V. (2009) Correlates of environmental factors and human plague: an ecological study in Vietnam. International Journal of Epidemiology 38, 1634-1641.

R Development Core Team. (2006) R: A Language and Environment for Statistical Computing. R Foundation for Statistical Computing, Vienna. [www.ipensieri] Site visited on 06.09.2011.

Skolow, S.H., Foley, P., Foley, J.E., Hastings, A., Richardson, L.L. (2009) Disease dynamics in marine metapopulations: modelling infectious diseases on coral reefs. Journal of Applied Ecology 46, 621-631.

Tanser, F.C. \& Sueur, D. (2002) The application of geographic information systems to important public health problems in Africa. International Journal of Health Geographics 1, 4.

Vanwambeke, S.O., Bennett, S.N. \& Kapan, D.D. (2011) Spatially disaggregated disease transmission risk: land cover, land use and risk of dengue transmission on the Island of Oahu. Tropical Medicine and International Health 16, 174-185.

Wang, Y., Tobey, J., Nugrand, G.B.J., Makota, V., Ngusaru, A. \& Traber, M. (2005) Involving Geospatial Information in the Analysis of Land-Cover Change along the Tanzania Coast. Coastal Management 33, 89-101.

Williams, G.J., Aeby G.S., Cowie, R.O.M. \& Davy, S.K. (2010) Predictive Modelling of Coral Disease Distribution within a Reef System. PLoS One 5 (2), e9264.

Zhang, Z., Ward, M., Gao, J., Wang, Z., Yao, B., Zhang, T. \& Jiang, Q. (2013) Remote sensing and disease control in China: past, present and future. Parasites \& Vectors 6, 11.

Zimba, M., Pfukenyi, D., Loveridge, J. \& Mukaratirwa, S. (2011) Seasonal abundance of plague vector Xenopsylla brasiliensis from rodents captured in three habitat types of periurban suburbs of Harare, Zimbabwe. Vector-Borne and Zoonotic diseases. 11, 11871192.

Zuur, A.F, leno, E.N. \& Elphic, C.S. (2010) A Protocol for data exploration to avoid common statistical problems. Methods in Ecology and Evolution 1, 3-14. 